\title{
Virada da literatura e do pensamento no século XX: Intervenções da Estética da Recepção e da Desconstrução
}

Maria Antonieta Jordão de Oliveira Borba ${ }^{a}$

\begin{abstract}
Resumo
Apresentação dos principais aspectos das ideias de Hans Robert Jauss, Wolfgang Iser, Michel Foucault e Jacques Derrida, como propostas das mais representativas do corte epistemológico efetuado por duas grandes vertentes do século $X X$, respectivamente a Estética da recepção e a Desconstrução francesa. Desenvolvimento dos modos pelos quais cada uma dessas noções atuou, no interior de tais vertentes da década de setenta, para abalar as concepções metafísicas vigentes sobre literatura e pensamento ocidental.
\end{abstract}

Palavras-chave: corte epistemológico, recepção, desconstrução, efeito, interpretação. 
Duas vertentes de pensamento da segunda metade do século XX tornaram-se conhecidas por terem efetuado um corte no corpo do Estruturalismo, quando questionaram a principalidade de noções metafísicas nas reflexões sobre homem e sociedade. Referimo-nos à Estética da recepção e à Desconstrução francesa, que se expandiram a partir da década de sessenta, propondo novas formas de compreensão de mundo, linguagem, literatura, quando indagaram a primazia de concepções que não mais respondiam à literatura, às manifestações lítero-culturais de margem, às questões relativas ao homem, ao aparecimento de objetos etc.

Com os estudos recepcionais e desconstrutivistas, novas tematizações passaram a reivindicar seus lugares na história do pensamento, a ponto de não mais ser possível relegá-las a um plano subalterno, em especial os debates sobre sujeito, arte, linguagem, literatura, cultura, sociedade. Mesmo considerando as diferenciações entre as correntes iniciais do século XX - Estilística, Formalismo eslavo, New criticism, Escola morfológica alemã -, observa-se que possuíam em comum uma metodologia de base estrutural e de submissão a princípios valorizadores do legado da filosofia de Platão, decorrentes da dicotomia sensivel e inteligível. Fato é que a Estética da recepção e a Desconstrução, ao romperem com a base dual do Estruturalismo, contribuíram significativamente para a instauração de um solo propício a um novo entendimento sobre as relações entre as palavras e as coisas, inaugurando o período que costumou ser designado por pós-modernidade ${ }^{1 .}$

Tendo em vista a prosperidade dos acontecimentos, consideramos pertinente desenvolver um estudo que, num mesmo espaço, trate do limite e alcance dos desdobramentos da ruptura instaurada nas últimas décadas do século XX. Este artigo deverá, pois, desenvolver os aspectos gerais de duas importantes grades teóricas que emergem no interior da Estética da recepção e da Desconstrução. Referimo-nos, respectivamente, à Teoria do efeito de Wolfgang Iser e às ideias sobre recepção de Hans Robert Jauss, por um lado, e, por outro

${ }^{1}$ Empregamos aqui a expressão pós-modernidade sem entrar na discussão que vem sendo feita sobre a inadequação do prefixo e da relação com o termo contemporaneidade. lado, às reflexões de Michel Foucault e Jacques Derrida no pensamento da Desconstrução. Articulados no referido marco epistêmico, Iser, Jauss, Foucault e Derrida puseram em xeque os alicerces do pensamento estrutural, desenvolvendo reflexões que vêm instigando debates até a contemporaneidade. 
${ }^{2}$ Essas noções foram assim tratadas por Hans Robert Jauss: "Resumo esta exposição na tese seguinte: a conduta de prazer estético, que é ao mesmo tempo liberação de e liberação para, realiza-se por meio de três funções: para a consciência produtora, pela criação do mundo como sua própria obra (poiesis); para a consciência receptora, pela possibilidade de renovar sua percepção, tanto na realidade externa, quanto na interna (aisthesis); e, por fim, para que a experiência subjetiva se transforme em intersubjetiva, pela anuência ao juízo exigido pela obra, ou pela identificação com normas de ação predeterminadas a serem explicitadas" (p.81). Escreve, ainda, o seguinte trecho: "Designa-se por katharsis [...] aquele prazer dos afetos provocados pelo discurso ou pela poesia, capaz de conduzir o ouvinte e o espectador tanto à transformação de suas convicções, quanto à liberação de sua psique" (LIMA, 1979, p. 81).
Em relação à atuação da Teoria do efeito na intervenção da Estética da recepção, observa-se que foi a entrada do leitor que fez com que o efeito de Iser (ISER, 1978) ou a atividade receptiva de Hans Robert Jauss (JAUSS, 1979, p. 43-62) dessem uma virada na crítica da literatura, fazendo com que as análises praticadas pelas correntes críticas tivessem, significativamente, abalados seus pressupostos. Como se sabe, com a fundação da Estética da recepção, Jauss deu ampla visibilidade ao leitor, quando tornou pública a importância de Iser, declarando que seu parceiro da Escola de Konstanz contribuiu decisivamente para a teoria da recepção ao criar uma teoria do efeito. Sabe-se que Jauss foi quem primeiro tratou da premência de se pensar uma história da arte que investigasse a experiência estética, o que implicava uma narrativa que autorizasse a função do leitor, colocasse o foco na práxis estética e entendesse a atividade artística como atividade produtora, receptiva e comunicativa, a saber, poiesis, aisthesis e katharsis ${ }^{2}$ (JAUSS, 1979, p. 63-82). Importante lembrar ainda que, em Jauss, a experiência primeira de uma obra de arte se realiza no seu efeito, no momento do texto, a saber, na "compreensão fruidora" (JAUSS, 1979, p. 46), e não naquele em que se faz a interpretação. É nesse sentido que preconizava uma hermenêutica literária que estabelecesse a diferença entre dois modos de recepção: "aclarar o processo atual [atual como momento da obra] em que se concretizam o efeito e o significado para o leitor contemporâneo" [...] e o de "reconstruir o processo histórico pelo qual o texto é sempre recebido e interpretado diferentemente por leitores de tempos diversos" (JAUSS, 1979, p. 46). O objetivo de Jauss era comparar o "efeito atual (o do texto) com o desenvolvimento histórico da experiência e formar o juízo estético, com base em duas instâncias: efeito e recepção" (JAUSS, 1979, p. 46). Curioso constatar que, apesar de os formalistas Vitor Chklovski (1978) e Tzvetan Todorov (2013), por exemplo, não terem conceituado o leitor ao definirem a desautomatização de percepção, havia, nesse conceito, um sujeito que, fora do texto, experimentava o "estranhamento" decorrente da interrupção da percepção automática. O certo é que o foco na matéria prima verbal, mesmo com a entrada do contexto pela crítica sociológica, permaneceu sem significativos abalos até o aparecimento da Estética da recepção, em especial com Wolfgang Iser. Vejamos. 
A Teoria da literatura que se construiu segundo a clave do pensamento estruturalista orientou suas práticas metodológicas, apoiando-se na noção de estrutura, sempre em função de um quadro definido de categorias: sistema, modelo, sintagma, paradigma, relações formais. Na primeira metade do século XX, o emprego dessas noções situava a análise e a concepção de literatura no interior de um universo estrutural, cuja fonte era notadamente a Linguística saussuriana. Com a Teoria do efeito, Iser passou a examinar uma nova formulação que, desligada desse quadro estrutural, endereçou sua concepção de literatura para um outro campo de reflexão, o campo da Pragmática. A substituição da Linguística estrutural pela Pragmática revelou o deslocamento do olhar para o texto literário nos limites de suas páginas para entender, de modo exclusivo, a interação que ele mantém com o leitor. Estabeleceu-se, assim, uma saída da literatura em seus aspectos intratextuais, séries intertextuais, características realistas ou não realistas, para a compreensão de sua interação com aquele que lê. Pela perspectiva da Pragmática, Iser desligou-se da definição das significações a partir de uma sintaxe verbal para pensá-las em função das repercussões, respostas ou reações de quem se aproxima da obra. Com isso, sua teoria negou o exame do texto pautado na distância temporal que separa a crítica do objeto de leitura, para dar lugar a uma aproximação com a ficção, pela qual o teórico quer verificar como se dá o próprio processo de leitura.

As primeiras reflexões de Wolfgang Iser em The act of reading (ISER, 1978) - obra em que nos deteremos para apresentar sua incisiva contribuição à Estética da recepção no abalo que provocou - problematizam a questão da permanência de normas clássicas na interpretação do fenômeno artístico. Para isso, dizia que os preceitos da tradição só firmaram sua aplicabilidade enquanto a própria obra pretendeu ser uma representação das totalidades de uma época ou mesmo de uma verdade universal. De fato, houve um momento em que a arte - e, portanto, a literatura - foi entendida como portadora de um significado revelador das condições sociais de seu tempo. Daí firmaram-se atividades críticas, que teriam por função desenterrar o significado da obra. Dava-se então continuidade inclusive à concepção vigente desde o século XIX, quando se entendia a arte como reflexo dos valores predominantes do 
sistema, deixando de lado as transformações intrínsecas à arte moderna, que vinha ensinando a ver que ela "não pode mais ser considerada como imagem representativa de tais totalidades, e que uma de suas funções básicas é revelar, ou talvez mesmo equilibrar as deficiências resultantes dos sistemas prevalecentes". (ISER, 1978, p. 12) Em suas ideias sobre comunicação da obra com o leitor, Iser percebeu que era preciso substituir o gesto platônico - gesto que interpretava a arte numa correspondência entre a ideia e a aparência - por um outro que se pautasse numa nova perspectiva, conforme declara em seu The act of reading: "o ponto focal agora é a interação do texto, com as normas históricas e sociais de seu ambiente, de um lado, e, de outro, a disposição potencial do leitor" (ISER, 1978, p.14). A ênfase atribuída ao significado na dependência do processo de comunicação revela bem a diferença entre as teorias clássicas sobre literatura e a Teoria do efeito estético. Se o significado só se efetivava num ato de comunicação, era porque a análise formalista, ao descartar o receptor em nome da primazia da obra, esteve sempre pressupondo o significado guardado como um valor semântico do texto. A partir dessa ideia de pertencimento de significado, e não de doação, entendia-se a literatura como resultado de uma série de estratos, sendo sua dimensão última uma camada semântica. Se assim era, a tarefa do analista, nas correntes estruturalistas em geral, se limitava a resgatar o significado guardado em sua camada mais profunda. Essa semântica escondida, por sua vez, nada mais significava do que a noção de verdade, que, na arte, como previu Iser, assumia sua mais "perfeita forma" (ISER, 1978, p. 12).

Em contraposição à ideia clássica de semântica guardada na literatura, Iser propôs uma teoria que caracteriza o discurso ficcional por uma dimensão imagética (ISER, 1978, p. 136-137). O caráter próprio do significado imagético é não ter um lugar onde se encontra, até porque a noção de imagem supõe algo que, ao mesmo tempo, é dado e retirado, tal como uma sombra que se desloca sempre para outro lugar, quando dela se aproxima a figura que lhe dá origem. Com Iser, a dimensão imaginária da ficcionalidade acarretou um conceito de significado que perde seu caráter de unicidade: o significado passa a ser visto como polimorfo porque depende das múltiplas possibilidades de imagens passíveis de serem formadas pelo leitor. 
O pressuposto que prescreve um significado de caráter imagético constituiu uma das condições para que Iser afirmasse a construção de significação distinta das correntes críticas que o precederam. Não sendo mais construção de um sujeito especial - o crítico da literatura -, deixou de importar a atitude metodológica que se pauta numa referencialidade geradora de um significado histórico, sociológico, psicológico. Também não interessava mais a busca da semântica que abandonasse a referencialidade - tal qual os New critics - e se concentrasse nos aspectos puramente verbais da obra. $\mathrm{Na}$ Teoria do efeito, o significado não está nem no texto, nem fora dele. É inter-relacional. Por isso, só pode ser resultado da interação entre os signos textuais e os atos de compreensão do leitor. Deixa também de fazer sentido a divisão sujeito/ objeto, pois o significado não é um objeto que se define, mas um efeito a ser experimentado. Se a obra não mais se confunde com o texto, se o significado é fruto de uma interação, o leitor passa a ter uma atuação efetiva na realização da literatura. Nas palavras de Iser, significado e obra se concretizam no trânsito entre dois polos: o polo artístico, o texto do autor, e o polo estético, a concretização do leitor. A cada um desses polos encontram-se relacionadas a estrutura verbal (polo artístico) e a estrutura de afeto (polo estético). Pelo caráter bilateral da ação comunicativa, a estrutura verbal - polo artístico - norteia o leitor, de modo que suas compreensões não se tornem arbitrárias, eliminando atitudes projetivas em que se lê o que bem quer e não o que é apresentado. Na outra ponta, a estrutura de afeto, referente ao leitor, promove o preenchimento daquilo que a linguagem do texto abre à imaginação. Assim, a atualização da obra tem início no polo estético, nos momentos em que o leitor passa a preencher os vazios do texto (ISER, 1978, p. 166). É nesse sentido que Iser afirma que o texto só se realiza no ato pragmático da recepção.

A caracterização dos vazios textuais e seu modo de complementação na Teoria do efeito se diferenciam do modo como a análise de base estrutural compreendeu esse conceito. Tradicionalmente, os vazios foram configurados por quebras no encadeamento, mudança de rumo da história, interrupção narrativa de uma de suas partes, enfim, sempre a um aspecto verificado no próprio enunciado da narrativa. Em Iser, o vazio supõe necessariamente a instauração de um fenômeno 
ocorrido entre a mente do leitor e o texto. Trata-se, portanto, da constituição de interrupções concernentes ao trânsito do leitor com o texto, quando este o convoca a dar uma resposta toda vez que sua percepção experimentar algo que venha da leitura da obra. Os vazios "constituem a estrutura fundamental do processo de comunicação, por se encontrarem intimamente ligados à premência de tal resposta a ser dada na assimetria entre texto e leitor" (ISER, 1978, p. 166). Se nas relações sociais a imprevisibilidade da experiência do outro forma um vazio nonada - que, no entanto, pode ser superado pelas convenções comuns aos atos de conduta prática dos sujeitos, "na relação texto/leitor, falta um quadro de referências semelhantes" (ISER, 1978, p. 167), pois os "códigos que poderiam regular essa interação são fragmentados no texto e, na maioria dos casos, precisam primeiramente ser construídos" (LIMA, 1979, p. 88).

Paralelamente aos vazios, Iser declara que a diversidade de situações tematizadas pelo texto, o grau de aceitabilidade de condutas de personagens, o espectro de valores endossados e rejeitados, tudo isso é acompanhado por convenções que não são necessariamente as mesmas pelas quais o leitor se conduz em sociedade. E para que a leitura se caracterize por um ato comunicativo, a Teoria do efeito prevê uma condição essencial: o leitor deve passar de sua posição de sujeito da realidade leitor real - (ISER, 1978, p. 34-36) para a de leitor implícito (ISER, 1978, p. 34). A cota de disponibilidade atua quando ele deixa, de lado, uma possível rejeição - valores morais, situações sociais, linguagem, caracteres dos personagens etc. - para promover a dose de identificação necessária que lhe permita penetrar no universo ficcional. Quando esse fenômeno de identificação e distanciamento é cumprido, passa a atuar uma tensão resultante da diferença entre o eu do leitor real e o outro eu do leitor implícito, já mobilizado para ler comportamentos regidos por normas que não são necessariamente as suas. Embora seja forte o papel do texto, o background e o quadro de referência trazidos pelo leitor nunca desaparecem; ao contrário, contribuem para bem alimentar a interação. Até porque, o leitor implícito constitui uma rede de estruturas que demandam respostas. É um constructo dessa estrutura, na medida em que as indeterminações se expõem às várias possibilidades de resoluções do que estiver em implicitude. Seja qual for 
sua natureza, situação histórica, condicionamento social, ao leitor é designado um papel a desempenhar, uma função na construção da obra.

Em relação ao polo artístico, Iser previu também condições de possibilidade para que seja capaz de suscitar uma ação comunicativa. A estrutura da ficção, mesmo que se alimente da realidade, deixa de reproduzir essa realidade quando o material do repertório é apresentado segundo as estratégias das "perspectivas textuais" (ISER, 1978, p. 35-36). Trata-se de um aspecto crucial da Teoria de Iser, pois é a partir dessa exigência que se revela uma concepção de literatura absolutamente específica.

Para configurar as condições de possibilidade relativas à estrutura artística - ou polo artístico - Iser se apropriou das ideias desenvolvidas na Teoria dos sistemas gerais por Jürgen Habermas e Niklas Luhmann (HABERMAS; LUHMAN, 1979), quando os autores definem realidade pragmática como sistema baseado em convenções e códigos sociais. Segundo Habermas e Luhman, qualquer sistema de mundo deve ser entendido como rede portadora de mecanismos reguladores, de forma a reduzir as incertezas das contingências de mundo, propiciando, assim, um quadro de referência para as ações dos sujeitos em sociedade. Ầ medida que tal controle entra em funcionamento, o sistema reivindica validade para certas normas ou convenções, num conjunto hierárquico e verticalizado, dispondo-as, nessa linha, em diferentes graus, desde as regras mais dominantes até as mais negadas. A partir dessa ideia de realidade pragmática, Iser vai dizer que a realidade da literatura abala a estrutura de realidade relativa ao sistema de mundo, pois, apesar de o universo ficcional se referir à realidade, não mantém o quadro vertical equilibrador de seu sistema. A ficção se apropria das convenções aceitas, sem, contudo, manter o mesmo estatuto social que elas possuíam antes de serem deslocadas para a obra. Esse tipo de reformulação, entretanto, não ocorre em qualquer literatura; somente quando a estrutura ficcional é construída em repertório e estratégias (ISER, 1978, p. 68-70).

$\mathrm{O}$ repertório diz respeito às variadas referências do texto que são apresentadas de diferentes formas: alusões literárias, normas históricas e sociais, dados do contexto cultural, enfim, todo e qualquer tipo de indicador da realidade extratextual. A obra literária em repertório incorpora esses dados, sem 
${ }^{3}$ Oleitor fictício é uma espécie de personificação de visões e expectativas históricas quando há o propósito de submetê-las a influências modificadoras de outras perspectivas, todas agindo interativamente. Iser escreve que o leitor fictício simplesmente revela as normas prevalecentes da época, formando uma base questionável pela qual a comunicação deve ser construída. ISER (1978), p. 153. referendá-los nem rejeitá-los. Assim, enquanto o sistema de mundo hierarquiza as convenções verticalmente, $a$ estrutura do repertório apresenta-as por uma estranha forma de combinação, através do processo de reagenciamento horizontal (ISER, 1978, p. 107-132), de modo a torná-las desprovidas da validade que possuíam no contexto referencial. Esse reagenciamento é realizado através das perspectivas textuais que, na Teoria do efeito, são constituídas pelo narrador, personagens, enredo, leitor fictício $^{3}$ (ISER, 1978, p. 153). São elas as responsáveis pelo modo como a narrativa apresenta as informações da narrativa, o que vem revelar tanto o modo como Iser concebe a literatura, quanto a estratégia de caráter estético. Sua movimentação se incumbe de construir a tal estranha forma de combinação, exercendo a função de desfamiliarizar o familiar. E é essa despragmatização a responsável pela suspensão das regras pragmáticas na leitura da ficção, pelo vazio, pela resposta a esse vazio.

Ao reorganizar horizontalmente as normas, o texto ficcional reduz o grau de variabilidade daquilo que, no plano de realidade, se apresenta como um espectro abrangente de convenções, regras, normas sociais. Tal redução se deve ao fato de, na literatura, as convenções serem expressas de tal maneira inesperada, que ficam desprovidas de suas validades e sujeitas a exame. A encenação de regras, por estar sendo representada na ficção, impede que tenha a eficácia que lhe era peculiar em sua realidade de origem, acarretando ausência de nitidez dos códigos subjacentes. Na ficção, a encenação permite que o leitor veja, à distância, aquilo que está nele. O leitor se vê através da convenção, quando não mais atua por ela. É por isso que, ao despragmatizar ou alimentar as indeterminações, o discurso ficcional da literatura passa a exigir uma resposta - response - do receptor.

Em resumo, a tensão entre leitor e texto na reorganização das normas pelas perspectivas textuais acaba por compor uma moldura dos mecanismos perceptivo e cognitivo processados por quem recebe a obra: o leitor passa pelo efeito estético, ao experimentar a tensão própria do familiar desfamiliarizado; distingue as convenções que o norteiam em sua ação social, uma percepção que, segundo Iser, não era possível enquanto sua própria conduta estava sendo guiada pelas regras em sociedade" (ISER, 1978, p. 95); sente-se mobilizado a dar uma resposta - (response da transmutação discursiva do efeito) à 
experiência estética, "resposta" esta que, sendo de ordem cognitiva, implica repensar as convenções que o atravessam enquanto sujeito de sociedade. Daí ser possível concluir que, em Iser, a literatura, possibilita que o leitor saia do discurso ficcional de forma diferente da que entrou e, assim, atue em sociedade.

Um outro acontecimento da década de setenta que promoveu uma ruptura no pensamento do Ocidente, intervindo diretamente na principalidade das visões de mundo, foi a Desconstrução francesa. Como se sabe, o movimento radicalizou o pensamento da tradição, ao partir de pressupostos que respondiam às novas relações que o sujeito mantinha com o discurso, a história, a cultura. As ideias dos filósofos da Desconstrução permanecem como referências profícuas no subsídio de pesquisas várias, dentre elas, as manifestações líteroculturais de margem, ao revelarem a fragilidade do pensamento hierarquizador do centro e estruturante dos paradigmas binários. Comprometidos com essa ruptura, é na Desconstrução que se sobressaem dois importantes pensadores do século XX: Michel Foucault e Jacques Derrida. Repensando a história das ideias e revisando a história da filosofia, os filósofos franceses, ainda que por princípios diferentes daqueles que nortearam a Estética da recepção, contribuíram para o corte efetuado no Estruturalismo quando puseram em xeque a principalidade dos princípios metafísicos do legado platônico, abalando noções como continuidade histórica, unidade do sujeito, profundidade discursiva, valor de autoria, paradigma binário, verdade do discurso.

Várias foram as noções desenvolvidas por Michel Foucault e Jacques Derrida que, remetendo diretamente para a cadeia dos signos, caracterizaram o discurso e a interpretação pela noção de superfície. Correlatos a esses conceitos, agrupam-se outros como sujeito, fragmentação, descontinuidade, jogo, força, traço, escritura, diferença, indecidibilidade, descentramento. Tais estratégias nocionais, por sua vez, só puderam ser desenvolvidas em função das rasuras operadas por Nietzsche, Freud e Marx, quando surgem na modernidade europeia. Foi com base nas reflexões desses filósofos que Foucault e Derrida desenvolveram seus próprios campos conceituais, respectivamente sobre a história das ideias, na proposição da arqueologia do saber

${ }^{4}$ Fono-logo-centrismo remete para a crença de que a escrita é inseparável da fala, que se confunde com o ser em presença no discurso. e da genealogia do poder, e sobre o fono-logo-centrismo ${ }^{4}$ da metafísica ocidental, na proposição da Gramatologia.

Das variantes correlatas ao conceito de interpretação, duas das mais significativas noções em Nietzsche, Freud e Marx 
dizem respeito à crítica da profundidade e da verdade do discurso. É o que escreve Foucault (FOUCAULT, s/d) sobre o pensamento de Marx, ao lembrar, por exemplo, a platitude pela qual nomeou os estudos profundos sobre a moeda, o valor e o capital. A negação desse palimpsesto se evidencia também quando Marx, interessado pelas relações de produção, entendeu-as como se oferecendo à interpretação, o que fez com que abandonasse o trajeto formado pela história de tais relações e sinalizasse para a noção de descontinuidade. A revisão da profundidade em Nietzsche ocorre quando reflete sobre a crença no abismo da consciência, definindo-a como um engenho dos filósofos. Nietzsche nega os conceitos de ser e de verdade que percorreram a metafísica ao dizer que o caminho em direção a solos profundos, por obrigar a retirada da terra da superfície, só faria revelar a exterioridade ou a superfície dessa profundidade. Suas reflexões mostraramse contrárias ao princípio subjacente à suposta capacidade de o sujeito atingir a verdade quando ativasse suas propriedades cognitivas. Do mesmo modo que em Nietzsche e Marx, as reflexões de Freud apresentaram sinais de rejeição à concepção de que o conhecimento ocupava um lugar distante daquele pelo qual um objeto se oferece à interpretação. $\mathrm{O}$ inconsciente como portador de uma gramática estranha ao homem e da ideia de submissão da linguagem à indistinta operação do inconsciente criam um impasse à investigação do discurso como condição de verdade. Os pensamentos de Nietzsche, Freud e Marx romperam, pois, com a ideia de que interpretar exigiria escavar as profundezas da linguagem. Para eles, quanto mais a interpretação avançasse para o suposto encontro com a verdade, mais se aproximaria da morte. Implícito a qualquer tentativa nessa direção, permaneceria o falso pressuposto de que a investigação do símbolo conduziria à coisa em si, como se este símbolo vivesse uma origem que lhe pertencesse ou fosse a própria coisa que apenas simboliza.

A leitura de Nietzsche, Freud e Marx realizada por Foucault (FOUCUALT, s/d) permitiu-lhe efetivar um novo olhar para a história em suas relações com o saber e o poder, o que de início se deu através de seu projeto arqueológico e, posteriormente, com o projeto genealógico. Praticado de modo explícito em As palavras e as coisas (FOUCAULT, 1966) e aprofundado em A arqueologia do saber (FOUCAULT, 1972), o projeto arqueológico revestiu-se de caráter inaugural, ao se opor à existência de determinadas unidades fixas 
a regularem as produções discursivas. Para Foucault, os discursos deveriam ser analisados não mais por unidades que os classificam em função do objeto, da forma de enunciação, conceitos, temas, mas pela própria dispersão em que se encontram. Esses dados deixaram de constituir regras de formação do discurso porque Foucault caracterizou-os como reguladores, isso sim, no aparecimento das produções discursivas. São os próprios enunciados e objetos dispersos que estabelecem as condições de possibilidade de suas emergências. Referindo-se ao discurso psiquiátrico e ao objeto dessa formação discursiva, por exemplo, as análises arqueológicas de Foucault, como a História da loucura (FOUCAULT, 2007) ou o Nascimento da clínica (FOUCAULT, 2011), revelaram mais claramente a significativa relação entre as produções discursivas e os acontecimentos.

Agindo no campo da epistemologia, Foucault compreendeu a história das ideias de modo diferente dos que a afirmavam como evolução da racionalidade. A história das ideias constitui-se como relação que uma ideia estabelece com outras, sempre por rupturas. $\mathrm{O}$ interesse, portanto, deixava de ser a definição do discurso e passava a ser a indagação dos motivos pelos quais uma episteme possibilitou o surgimento de um discurso, ou ainda, a indagação de por que e como um objeto pôde aparecer. A caracterização dos solos epistemológicos vinculou-se à determinação de regras de aparecimento, o que passou a implicar a análise das condições de possibilidade de suas irrupções. A história arqueológica foucaultiana propôs-se a interpretar estruturas que percorrem os períodos por meio da investigação de acontecimentos que, em suas dispersões, foram esquecidos pela história tradicional. Daí ter compreendido a formação das ideias pela descontinuidade, o que fez com que a tradicional classificação dos períodos em sua linearidade deixasse de ter sentido. Nessa ordem, a interpretação de um determinado objeto (doença mental, sexualidade, representação pictórica) supõe que esse objeto participa de uma história que lhe é própria, independente do percurso que fez.

Todo o movimento provocado pela reflexão foucaultiana em torno de descontinuidade, sujeito fragmentado, solo epistemológico avizinha-se de aspectos correlatos a uma concepção de interpretação. Como não havia nada anterior ao signo, tudo deveria ser considerado já como interpretação e essa tarefa nada mais significava do que estabelecer um jogo inacabado: "Se a interpretação nunca se acaba, isto significa que não há nada a interpretar; tudo é interpretação, cada símbolo é não a coisa que se oferece à interpretação, mas a interpretação de outros símbolos" (FOUCAULT, s/d, p. 16, grifo meu). 
O propósito de construir um panorama da Desconstrução traz necessariamente para debate o nome de Jacques Derrida no mesmo nível de relevância atribuída ao de Michel Foucault. Derrida pôs em crise tanto a atividade estruturalista a que se vinculou, quanto os pressupostos de um quadro mais amplo, o da filosofia ocidental. Marcando as bases fono-logo-cêntricas que sustentaram o pensamento te(le)ológico, o filósofo abalou uma série de conceitos dominantes, sem contudo simplesmente virar a página da filosofia: "não tem nenhum sentido abandonar os conceitos da metafísica para abalar a metafísica; não dispomos de nenhuma linguagem de nenhuma sintaxe e de nenhum léxico - que seja estranha a essa história. (DERRIDA, 1971, p. 233). Sua Gramatologia (DERRIDA, 1973) propôs-se a repensar conceitos da metafísica, examinando-os a partir de um gesto que consistiu em ler os filósofos de uma certa maneira. Isso significou dizer que só era possível criticar a metafísica usando a mesma escrita por ela empregada, até porque a gramatologia não pertence à língua, mas à noção de escritura.

Os caracteres finalista e religioso que orientam as bases te(le)ológicas da metafísica giram em torno da noção de centro e respondem pelas denominações de arquê, telos, deus, recebidas por esse centro. Entretanto, à medida que o centro se refere a um ponto da estrutura do discurso, pode, indiscriminadamente, ser denominado por origem, consciência, arquê, telos, deus, homem, todos esses designando a invariante de uma presença, que Derrida denominou significado transcendental. Edificou-se a metafísica pelo pré-conceito de que a phoné, inseparável do logos, confundia-se com a presença do ser. O filósofo sabia bem que a crença numa escrita de natureza puramente fonética só encontrava suporte no pensamento platônico, segundo o qual a verdade, ligada à Ideia, podia ser buscada com a presença daquele que fala. A interpretação configurada nessa ordem de pensar sempre afirmou o homem, "sonhou a presença plena, o fundamento tranquilizador, a origem e o fim do jogo" (DERRIDA, 1971, p. 249). Daí o gesto de a metafísica querer, continuamente, estancar a mobilidade própria de qualquer estrutura, sua estruturalidade, quando era atribuído ao discurso um ponto de presença ou uma origem fixa. Foi assim que Derrida explicou o fato de o significado ter sido sempre privilegiado, o que, por sua vez, promovia o recalcamento da própria força do significante.

$\mathrm{Na}$ revisão do Estruturalismo feita por Derrida, ficamos sabendo por que o pensamento das Ciências humanas e sociais no Ocidente fixou-se na ideia de centro e quais foram as consequências 
da base binária privilegiada. Como dissemos anteriormente, os procedimentos formais colavam a metodologia nos elementos opositivos por se pautarem na clássica oposição de Platão entre o sensivel e o inteligível, a essência e a aparência. Por essa perspectiva, a metafísica armou suas oposições, separou e hierarquizou fala e escrita, privilegiando aquela e rebaixando esta. À fala estiveram relacionados o inteligivel, a essência, o verdadeiro, o dentro; à escrita, o sensivel, a aparência, o falso, o fora. Derrida argumentou que, se o espaçamento entre os signos revelava a impossibilidade de uma escrita puramente fonética, era preciso pensar essa escrita como escritura. A escritura, por ser anterior à escrita, é traço mnemônico, anterior, pois, à linguagem do sujeito; [ ] não pode ser nem representação de imagem, nem "depende de nenhuma plenitude sensível, audível ou visível, fônica ou gráfica" (SANTIAGO, 1976, p. 30). Sendo anterior a qualquer oposição (inteligível/sensível; essência/aparência; verdadeiro/falso), a escritura é uma différance, um pharmakon com toda a indecidibilidade a suscitar um jogo entre seus significantes. A escritura nega a primariedade da fala, mata o pai, configurando-se por um jogo indecidivel, um pharmakon, tal como aparece no mito do nascimento da escrita, remédio e veneno, simultaneamente como duas forças.

Ora, o que marca então a distinção entre a interpretação clássica e a interpretação derridiana? Enquanto a atividade analítica do estruturalismo em geral abandonava a diferença em si-différance-, ou o momento anterior à diferenciação, para Derrida o que importava era justamente essa différance. Na différance, os termos ainda não se encontram distinguidos em seus significados opostos. Para melhor ilustrar esse fenômeno de anterioridade dos signos, diríamos que o texto seria comparável a um palco, onde há o proscênio e o fundo da cena. Somente no momento em que se escreve, fica determinado qual significante ocupa o proscênio, o que permite melhor compreender por que a escrita sempre promove um recalcamento de significado. $\mathrm{O}$ fenômeno pode ser ainda exemplificado através do próprio grafema da palavra différance. $\mathrm{O}$ a só marca sua presença e caracteriza o conceito de différance quando se faz uso da língua escrita. A sonoridade da fala francesa não deixa que se distinga différance - a anterioridade da diferenciação - de différence, momento em que os significantes apontam para outros significados. Se a escrita tem esse poder de recalque do significado, a interpretação pode vir a ser cúmplice do gesto que, tal qual a metafísica, busca o centro, ou o significado 
transcendental. A interpretação, para Derrida, diferentemente, significa fazer proliferar o próprio significante.

Quando Derrida pensou no conceito de différance, propôs, simultaneamente, os de escritura, pharmakon, interpretação. A interpretação que trabalha com a différance ativa o pharmakon, não se decide por um significado específico do signo, deixa emergirem as forças de remédio e veneno, de bem e mal, enfim, de todas as oposições, de todas as distinções, de todas as différennces passíveis de verificação. A interpretação derridiana não se configura por uma leitura ideológica, tal qual como fez a história do sentido - o sentido te(le)ológico - pautada no centramento do discurso (crença no valor de verdade da palavra e do ser enquanto presença) - fonologo-centrismo - e numa cultura de referência - etnocentrismo. Deixa emergirem o significante e a força do texto. A interpretação implica, nesse sentido, promover o descentramento da estrutura, isto é, não frear a mobilidade que lhe é própria, e sim ativar-lhe o próprio jogo. Derrida propôs então um conceito de interpretação que trabalhava com as noções de jogo, diferença, indecidibilidade, escritura, ausência do ser. A metáfora do pharmakon ilustra bem a atividade interpretativa que, ao invés de se decidir por um signo, impulsiona a força do significante. Desse modo é que se torna possível fazer falarem as potências do remédio e do veneno, do bem e do mal, do claro e do escuro, enfim de todas as oposições, de todas as différences. O signo, liberto agora de um significado transcendental, conceitua o significante como falta que poderá, a qualquer instante, ser preenchido por múltiplas significações. A significação nada mais é do que uma constante substituição de significantes. Não mais complementa a literatura, não mais a explica. Ao invés, o signo-literatura e o signo-texto constituem suplementos. Por essa diretriz, a interpretação será sempre um significante a mais que se acrescenta ao texto-base; é um suplemento do suplemento, uma interpretação da interpretação.

As reflexões aqui desenvolvidas sobre a virada do pensamento no século XX puderam revelar que tanto os teóricos da recepção, Wolfgang Iser e Hans Robert Jauss, quanto os da Desconstrução, Michel Foucault e Jacques Derrida, contribuíram para que estudos sobre literatura e cultura rompessem com noções predominantes até os anos 70, ao entenderem que as textualidades não mais se ofereciam como guardiães de uma verdade, ou com as profundezas, o que permitiu que aspectos relegados a planos ditos subalternos passassem a atuar. A entrada em cena do leitor e a possibilidade de a margem 
ser interpretada por seus objetos dispersos mudaram o panorama do século XX. O mundo, a literatura, a cultura passaram a ser entendidos por novos ângulos. Em Iser e Jauss, como podemos concluir, a atribuição de significação demanda "construção" de sentido por parte do leitor que vivencia uma experiência e, em Foucault e Derrida, as compreensões das manifestações lítero-culturais implicam "desconstrução", uma atitude do sujeito que se caracteriza por promover o deslizamento das interpretações, interpretações essas que são pulverizadoras de significações tanto do signo linguístico quanto do visual. De qualquer modo, com as reflexões dos teóricos da literatura e da filosofia, deixou de ser possível reivindicar a unicidade de leitura, a exclusividade da voz autoral ou da crítica e, com igual ênfase, a ideia de que a literatura guarda uma semântica a ser (des) coberta por aquele que dela se aproxima.

\section{REFERÊNCIAS}

AUSTIN, John Langshaw. How to do things with words. Oxford, Oxford University Press, 1980.

BORBA. M. Antonieta Jordão de O. Teoria do efeito estético. Niterói: Editora da UFF, 2003.

DERRIDA, Jacques. Gramatologia. São Paulo: Perspectiva, 1973. Perspectiva, 1971. A escritura e a diferença. São Paulo: Editora

DUQUE-ESTRADA, Paulo César (org.) Às margens - a propósito de Jacques Derrida. São Paulo: Loyola/ 2002.

FOUCAULT, Michel. A arqueologia do saber. Petrópolis: Editora Vozes, 1972.

As palavras e as coisas. São Paulo: Livraria Martins, 1966. A ordem do discurso São Paulo: Edições Loyola, 2001.

FREUD, Sigmund. A interpretação dos sonhos (Partes 1 e 2). Rio de Janeiro: Imago, 1976 (Edição Standard Brasileira das obras completas de Sigmund Freud), volumes IV e V.

GADAMER, Hans Georg. Truth and method. London, Sheed and Ward ed. John Cumming and Gerret Barden, 1979. 
HABERMAS, Jürgen. Pensamento pós-metafísico. Estudos filosóficos. RJ: Tempo Brasileiro, 1990.

ISER, Wolfgang. The act of reading. A theory of äesthetic response. London: Routledge \& Kegan Paul, 1978.

O fictício e o imaginário. Perspectivas de uma antropologia literária. RJ: Eduerj, 1996.

. Os atos de fingir ou o que é fictício no texto ficcional in: COSTA LIMA, Luiz (org.). Teoria da literatura em suas fontes. Rio de Janeiro: Francisco Alves, $2^{\mathrm{a}} \mathrm{Ed}$.

JAUSS, Hans Robert. A história da literatura como provocação à teoria literária. São Paulo: Ática, 1994.

O prazer estético e as Experiências Fundamentais da Poiesis, Aesthesis e Katharsis. In: LIMA, Luis (org.). A literatura e o leitor - textos de Estética da Recepção. Rio de Janeiro: Paz e Terra, 1979, p. 63-82.

A Estética da Recepção: Colocações Gerais. In: LIMA, Luiz Costa (Coord. e Trad.). A literatura e o leitor: Textos de estética da recepção, edição revisão. Rio de Janeiro: Paz e Terra, 1979, p. 43-62.

LIMA, Luiz Costa (org.) A literatura e o leitor. Textos de estética da recepção. Rio de Janeiro: Editora Paz e Terra, 1979.

ROCHA, João Cezar de Castro. Teoria da ficção: indagações à obra de Wolfgang Iser. Rio de Janeiro: Eduerj, 1999.

SANTIAGO, Silviano. Uma literatura nos trópicos. São Paulo: Editora Perspectiva, 1978.

. (Supervisão). Glossário de Derrida. Rio de Janeiro: Livraria Francisco Alves Editora, 1976.

SOUZA, Roberto Acízelo de. Teoria da literatura. São Paulo: Ática, 1986, Série Princípios, $1^{a}$ ed.

TODOROV, Tzvetan. Teoria da literatura - textos dos formalistas russos. Trad. de Roberto Leal Ferreira. São Paulo: Ed. da UNESP, 2013. 


\section{Abstract}

The turnaround of literature and thinking in the XXth century: Interventions of the Reception Aesthetics and Deconstruction

Introduction of the main aspects of the ideas of Hans Robert Jauss, Wolfgang Iser, Michel Foucault and Jacques Derrida, as some of the most important proposals of the epistemological rupture carried out by two major lines of the XXth century, respectively the Reception Aesthetics and French Deconstruction. Development of the modes whereby each of these notions occurred in such lines in the 70s, to disrupt the metaphysical conceptions on Literature and Western Philosophy.

Keywords: epistemological rupture, reception, deconstruction, effect, interpretation. 